УДК 821.163.41-992.09 Петровић М. https://doi.org/10.18485/godisnjak.2021.16.13

Јелена Г. Гребовић*

Универзитет у Београду

Филолошки факултет, докторанд
Оригинални научни рад

Примљено: 28. 09. 2021.

Прихваћено: 05. 11. 2021.

\title{
МЕТОДИЧКИ ПРИСТУП ПУТОПИСУ У ЦАРСТВУ ГУСАРА МИХАИЛА ПЕТРОВИЋА АЛАСА
}

Обрада путописа је један од најинтересантнијих, али и најкомплекснијих феномена наставне праксе. Путопис У царству гусара до сада није био предмет целовитог и систематичног методичког проучавања у српској књижевности. При проучавању се најпре отвара питање теоријског одређења овог дела. Како путописна књижевност представља посебан вид књижевности, аутор је настојао да прикаже одлике путописа и значај путописне прозе у српској књижевности. Путопис је изразито отворена форма и у њему се могу пронаћи најразличитији типови дискурса, од историјског до есејистичког, до лирског и емотивног, што је и у Петровићевом случају тако, о чему ће бити речи у раду. Суштина рада је усмерана ка представљању важних аспеката у проучавању путописа, као и суочавања ученика са наведеним делом. Користиће се постојећа литература, указани ће бити пишчеви ставови о жанру, прошириће се контекст за разумевање путописа уз помоћ методичке и књижевно-теоријске литературе.

Кључне речи: путопис, Михаило Петровић Алас, У цุарству гусара, методика, приступ, српска књижевност.

Да нисам добио један глас више од Петра Вукићевића, никада се математиком не бих бавио. Живео бих на рекама Србије, не на броду, него у чуну.

*jecagrebovic@gmail.com 


\section{1. У царству гусара ${ }^{1}$}

У изарству гусара је други објављени путопис Михаила Петровића Аласа, настао лета 1932. године, у егзотичним крајевима света, а штампан је 1933. године у Српској књижевној задрузи. Сви прикази, као и сви критичари, били су сложни да је тема занимљива, а стил завидно добар (Пековић 1998: 301). Петровић истиче да су циљ његовог путовања подаци за научни рад, те пишчева напомена на почетку указује на разлоге настанка путописа - није путовао зарад одмора и мира као већина путописаца, већ ради науке.

У контексту тумачења целокупне Петровићеве литерарне делатности, путописима је посвећивана нарочита пажња. По наговору Павла Поповића, Михаило Петровић почиње да описује пределе које је пропутовао. Михаило Петровић није био први који је бележио важне и релевантне податке путујући разним пределима (и пре њега су то чинили етнографи, историчари, географи), али је своју научничку мисао први подредио свим осталим захтевима и потребама жанра не западајући у непотребно набрајање података и не нарушавајући наративни ток путописа (Богдановић 1933: 61). Циљ Петровићевог путописа је да подучи. Писао га је наглашавајући потребу да се што више сазна о другима. Одликују га занимљиве и питке реченице и веродостојно приказивање стварности. Петровић нуди забаву и поуку уз примену научног стила. Путопис $y$ царству гусара карактерише прецизност и објективности. Путописац се са великом пажњом односи према чињеницама, што многи проучаваоци повезују са његовим бављењем математиком. Слободанка Пековић истиче да је Петровић у својим путописима (објективни) посматрач, а не учесник. Основне особине путописа су: усредсређеност на човека, а не на природу, пределе или градове, поштовање чињеница и података и истанчан дар да се у најкраћим цртама проникне у човека и у суштину односа људи између себе или према природи (Трифуновић 1969: 97). Кроз свој путопис, Михаило Петровић приказује своју педагошку црту - жељу да пренесе знање. Како се читав живот бавио математиком, Петровић не даје себи превелику песничку слободу, наводе проучаваоци. Његов стил одликују контрола и одсуство сентименталности. Описи су објективни, детаљни, често и застрашујуће стварни.

Симболичан наслов путописа упућује на тему дела. Путопис критичари виде као својеврсну енциклопедију. Замишљен је тако да у седам

\footnotetext{
${ }^{1}$ Сви цитати из путописа $У$ ичарству гусара наведени су према издању Српске књижевне задруге 1933. године, са наведеним бројем странице након цитата.
} 
целина прикаже нешаблонско путовање преко Саргаског мора, Бермуда, Бахамских острва, Хаитија, Антила и повратка у Европу. Прва два поглавља приказују путовање кроз егзотичне пределе, да би трећи одељак, па све до седмог, био посвећен гусарству. Описи предела и острва које је писац посетио су обогаћени етимолошким предањима, а у дигресијама проналазимо математичке појмове уз помоћ којих читаоцима приближава ову егзактну науку. Петровић тежи да објасни сваки појам за који сматра да би био непознат. Пажњу му окупирају људи, њихов хумор и начин живот. Читалац као да има фотографију пред собом која живописно приказује људе. Поглавља почињу историјским и географским чињеницама о месту, а потом следе легенде или предања, као и различите занимљивости уочене у непосредном додиру са људима.

У актуелним школским програмима Михаило Петровић није заступљен као аутор. У ширем избору у читанкама, зависно од узраста, може се пронаћи неколико одломака из његове путописне прозе. Бавити се Петровићевим путописима у основној школи значи проширивати контекст за разумевање овог жанра, као и свих жанрова које он у себи садржи. Анализом Петровићог путописа може се пратити развој идеја и склоност ка појединим темама.

Актуелни школски програм још увек не предвиђа обраду путописа У иарству гусара, али аутор верује да би наставна пракса показала да би ученици снажно доживели ово дело, радознало би му пришли и радо би га препоручили за читање.

\section{2. Радозналост као мерило кретања}

С обзиром на то да се ученици нису до сад сусретали са делима Михаила Петровића, добрим мотивисањем се може наговестити привлачност путописне прозе, те планирати осврт, приказ или интерепретацију путописа $У$ царству гусара. Путовања и разговор о путовањима могу бити повод да се ученици мотивишу у стицању навике читања. Жанр путописа чини се да је недовољно заступљен у савременим књижевним токовима, па тако и у савременој настави Српског језика и књижевности у основној школи. Јован Делић истиче да је путопис једна од најинтересантнијих „бочних” струја у српској књижевности прве половине 20. века; то је струја која је водила ка оплемењивању „високих” жанрова српске прозе, приповетке и романа, а некада чак и лирске поезије (Делић 2004: 63). Јован Деретић такође говори о великом значају пута и путописа у српској књижевности. 
Путопис је документарни облик који описује догађаје, људе и утиске које је писац срео и доживео на неком путовању. Путопис је изразито отворена форма и у њему се могу пронаћи најразличитији типови дискурса, од историјског до есејистичког, лирског и емотивног. Разноврсност се примећује и у жанровском погледу, понекад се путопис пише у форми дневника, често је повезан са општеобразовном литературом (енциклопедијама, водичима). Путопис је хибридни жанр - најчешће се укршта са есејом, приповетком или романом. Путопис обележава жудња за даљинама. Циљ путописа је да поучи, да побуди истраживачку или авантуристичку страст, да забави, задовољи радозналост, али и да покаже ауторову памет, ученост, сензибилност, смисао за лепим, сналажљивост (Пековић 1998: 303). Путопис поштује хронологију путовања. Путописац пролази кроз различите просторе у времену. Постоји, дакле, синхронизација између времена и простора, а путопис је неизбежно субјективан.

Новија српска књижевност почиње одласком Доситеја у свет, односно бекством Растка Немањића у манастир. Највећи путници у старијој српској књижевности били су: Свети Сава, Доситеј Обрадовић, Вук Караџић. Са њима почиње стварање и обогаћивање српске књижевности путописним жанром. Када говоримо о путописима, постоје два типа - документаристички и уметнички. Њима је, осим истог мотива заједничка и линеарна композиција, која прати јунаково кретање и описује његове доживљаје. Оба типа своју структуру уобличавају низом епизода, мање или више лабаво повезаних, а перспектива приповедања је дата са становишта самог приповедача. Петровићев путопис припада документарном путопису придржава се чињеница и тежи објективности. Путописац показује велики интерес за културу земље или земаља о којима пише. Петровић прилаже историју земље коју је посетио, подробно описује места и знаменитости која је обишао, детаљно приказује природу, људе и њихове обичаје. Субјективност приповедања је особина која доминира у оба путописна вида. Путописе можемо повезати и са другим жанровима - авантуристичким или пикарским романом. Страст за путовањима проистиче из Петровићеве страсти према рибарству.

У српској књижевности путописе су писали Љубомир Ненадовић, Исидора Секулић, Растко Петровић, Јован Дучић, Милош Црњански и многи други писци. Путопис је жанр који је пружао многе могућности његовом аутору. Лако је прилагодљив различитим формалним и тематским захтевима свога творца. Може бити у прози или стиху, може бити написан као роман или писмо, може укључити фактографске податке или лични исказ аутора (Пековић 1998: 302). Суштина путописа је неухватљивост 
његовог облика. Свој процват путопис је доживео у доба просветитељства. Циљ путописа је био да подучи, пробуди истраживачку радозналост, разоноди, покаже ауторову памет, смисао за лепо. Путописи су се писали како би се описало нешто ново, егзотично, несвакидашње, непознато публици. Насупрот путописима Милоша Црњанског, Растка Петровића, Јована Дучића, Петровићев путопис је лишен култа националне снаге. ${ }^{2}$ Исидора Секулић је писац усамљености, жена која говори о смрти и пролазности, свеобухватној тишини. Она је у сагласју са оним о чему пише, физички описи одговарају њеним осећањима. Исидора успоставља присан однос са читаоцима.

Дучић у својим путописима трага за сопственим истинама. Сачињени су од чињеница, али управо су оне полазиште за трагање за суштином. ${ }^{3}$ Дучић видљиво користи као везу са невидљивим и тајанственим. Оно што чини суштину Дучићевог света је - лепота. Лепота је стварност о којој стално треба мислити. Он говори о свету као сопственој пројекцији стварности, а поставља се изнад публике.

Путописи Милоша Црњанског предмете спољног света настоје да учине предметима унутрашњег. Код њега је Исидора Секулић уочила сукобљавање стилова, велики уплив песничког. Његови путописи нису ни историјски, ни уметнички, већ је њихова суштина у љубави. ${ }^{4}$ Они су једна велика песма о љубави.

Растко Петровић, у својим путописима је и песник и путописац, и приповедач и романсијер. У први план ставља моћ људског говора. Феномен говора приказује све лепоте људског живота и судбине. Растко комбинује поетске описе, лирска расположења, призоре из живота људи, одушевљење лепотом њиховог тела, занимљивости, музику, културу, уметност.

Иако не спадају у оно што се сматра самим врхом српске путописне прозе, Петровићеви путописи имају значајно место у историји српског путописа. Писани су питко, занимљиво, са много података, веродостојно, уз примену научног стила. Михаило Петровић се труди да из свог путописа искључи лично, да пише мимо осећања. Настоји да више буде посматрач, а не учесник. Он је усредсређен на човека, поштује чињенице, има дар да проникне у суштину људских односа, или суштину људског односа према природи (Трифуновић 1969: 97). Петровић је објективни посматрач. За разлику од других српских путописаца, Петровић је лишио

\footnotetext{
${ }^{2}$ Видети више у Поетици хрватског и српског реализма, Р. Вучковића.

${ }^{3}$ Више видети у Фактографија естетског у путописној прози Јована Дучића, Т. Росић

${ }^{4}$ Видети више у Белешка уз путопис Љубав у Тоскани, И. Секулић
} 
своје путописе култа националног, он свет не упоређује са „нашим”. Стил је прецизан и крајње објективан. Истицао је да он није књижевник, а парадоксално, бивао је много више у књижевности него што је, можда, и желео. Трудио се да пише о ономе што је знао и видео, није дозвољавао да машта превлада. Михаило Петровић није могао да поднесе претерану (песничку) слободу (Пековић 1998: 310). Описи су детаљни, а свет често натуралистички приказан. Међутим, иако је желео да буде објективан, Петровић није успевао да то и доследно испуни, о чему ће бити речи. Објективност изостаје, као и потпуна дистанцираност.

\section{3. Жеља педагога да се знање пренесе}

Све је теже убедити и охрабрити младог читаоца да се упусти у ишчитавање и тумачење путописног жанра. То је још теже у данашњем времену када су све информације доступне на интернету у виду мултимедијалних садржаја где је све већ „приказано” или већ „виђено”. Млади читалац је дете дигиталног доба. Такав читалац тражи „брз” садржај. Пред наставника се поставља врло тежак задатак - како мотивисати ученике да прочитају путопис?

У контексту таквих размишљања, дата је кратка анализа путописа У изарству гусара. Намера је да се кроз анализу мотива, теме, симболике и времена настанка, композиције, посебности у делу, пишчевих размишљања, дигресија, описа назначе смернице које би наставник могао да користи у наставној пракси.

За интерпретацију или приказ путописа $У$ изарству гусара ученици се припремају уз претходно дате истраживачке задатке како би што боље разумели путописни свет. Усмеравање ученичке читалачке пажње је најбоље почети разговором о путовањима, јер је већина ученика путовала или би желела негде да отпутује. Најчешће ученици замишљају далека места која би волели да посете. Разговор о местима која су посетили је такође добар вид мотивације.

За ваљану обраду путописа У цзарству гусара у основној школи било би потребно планирати најмање два школска часа. На часу који претходи тумачењу, наставник би требало да пробуди радозналост ученика. Да би их припремио за тумачење, наставник даје истраживачке задатке за самостални рад код куће. На тај начин ће покренути свесну активност ученика која је од преке важности на часовима књижевности и језика. Примарни покретачи ученичке свесне активности су мотивисање и лична афирмација. Ученике треба заинтересовати за рад-мотивисати, и то примерима 
који су блиски њима и личним искуством (доживљена тематика), а то је претходно поменути разговор о путовањима.

С обзиром на то да је путопис по својој природи припада нефикционалној књижевности, један од првих корака у тумачењу путописног текста јесте његово смештање у укупни стваралачки опус писца, а како Петровић себе не сврстава у писце, то је нешто што би ученике требало да инспирише - чиме се онда овај „писац” заиста бавио? Путопис може бити подстицај да се шире проговори о пишчевом стваралаштву. Наставник припрема ученике за уметнички доживљај - питањима подстиче ученичку свесну активност: Зашто је Михаило Петровић специфичан као аутор? Шта би исте издвојили као посебно у путопису? Чиме ова књига побуђује пажњу читалаца? Наставник упућује на додатну литературу. Разговор о композицији путописа. Дискусија о посећеним местима, о временском периоду настанка путописа. Проучавање односа између наслова и тематике путописа. Симболика наслова. Тематска сагласност. Описи. Уочавање кључних мотива. Разговор о стваралачким поступцима. Пишчева размишљања. Пишчев живот и његови ставови о животу. Култура других народа. Изношење ученичких ставова о путопису $У$ йарству гуса$p a$, навођење одломака којим би друге мотивисали да прочитају ово дело.

Живот Михаила Петровића био је, како за ондашње време тако и данас изузетно занимљив - рођен у Београду, докторирао на Сорбони као најбољи студент генерације, занимао се за књижевност, писао, свирао виолину, путовао и оставио иза себе многобројна дела на корист будућим генерацијама. Професор математике на Великој школи, а касније на Београдском универзитету. Рођен је 1868. године и у великој мери је означио једну епоху у српској историји. Био је учесник Балканских ратова, а потом и Првог и Другог светског рата. Бавио се рибарством, отуд и његов надимак Алас. Човек радозналог ума и стваралачког духа. Математичар, морепловац, професор, виолиниста, писац и алас. Занесен науком, музиком и рибарењем. На прву експедицију је кренуо је са шездесет и три године, а током наредних пет година обишао скоро читаву земаљску куглу. Према белешкама са путовања су настали путописи и Роман Јегуље. Аутор је преко шездесет математичких радова, уџбеника и математичких часописа. Био је талентован музичар који је наступао у дорћолским кафанама на обали Дунава заједно са својим музичким друштвом СУЗ. Снимио је више од три стотине народних песама за Радио Београд, али нажалост, све изведбе су нестале током бомбардовања 1941. године. Умро је 1943. године у Београду, на Косанчићевом венцу, на војничком кревету окружен књигама. Најблиставији ум у историји математике, путописац, професор, 
музичар, Алас је задужио српски народ бавећи се сваком области прецизно, свим срцем, предано као мало ко до тад. Како је аутор одабрао методичку перспективу, уводни део часа се односи на живот и рад Мике Аласа који је пробудио ученичку заинтересованост. Петровићева свестраност, рад, преданост, ђаке подстиче да изуче и његов путопис - У цзарству гусара.

Обимни путописи које је написао Михаило Петровић настали су веома нагло, за разлику од његовог математичког дела, делимично и на наговор Павла Поповића. Све путописе је издала Српска књижевна задруга, а Политика је пренела његова „скраћена издања” (Анђелковић 2019: 182). Од петнаест томова Сабраних дела, Путописи чине два највећа.

Путописи Михаила Петровића могу се довести у везу са његовим бављењем математиком. Посебно је прецизан, јасан, педантан стил и врло сугестиван његов стил како наводи Михајло Пантић Алас уме занимљиво да приповеда о догођеним, а не измишљеним збивањима, и да језичкостилски артикулише област овладаног искуства, да документу дадне пуноћу који он изван контекста приче нема. Приповедање корене вуче из усменог наслеђа, из чувених аласких причања и рибарских приговарања, надлагивања, задиркивања, исмевања, надгорњавања (Анђелковић 2019: 159). Крајње оскудним средствима и без икакве сентименталности, писац постиже снажан емотивни набој у читаоца (Пековић 1998: 311).

Време настанка, несвакидашње путовање кроз егзотичне пределе, прикупљање материјала за научни рад буде ученичку заинтересованост да приступе путопису као што чини и Петровић - са жељом да науче нешто ново и несвакидашње. Мало ко је и данас у могућности да путује пределима којима је Алас путовао. Оригиналности ове прозе допринеле су и фотографије које је Петровић снимио.

Наслов У изарству гусара може да заинтригира и пробуди занимање за путопис. Шта се то крије иза царства гусара и зашто се писац одлучио за тај назив? Наставник пита ученике да ли знају шта су то гусари. Велики број ученика ће знати да су то морски разбојници, међутим, верујемо да неће знати како и зашто су гусари настали и чиме су се заиста бавили. Читајући дело, ученици ће закључути да је основни мотив путописа, уједно и његова кључна тема - мотив гусарења, односно гусарење.

Путопис је подељен на поглавља, а свако од њих носи свој назив, и то на основу тематских и идејних својстава. Прву целину чине приче о посећеним местима, док другу творе приче о гусарима. Наративне целине су структурално и тематски повезане, представљене следећим насловима: Од франиуске обале до позорнище антилског гусарства, Франиуски антили и повратак у Европу, Повод антилског гусарства, Регуларно гусарство 
у другим морима, Морски пирати, Женски гусари и Данашњи трагови антилског гусарства. Путописац приповеда на енциклопедијски начин који је често лишен личног утиска који се спорадично огледа у дигресијама и дескрипцијама које су многобројне, те је упитно, као што тумачи кажу, да је његов стил објективан. Оне откривају емоције од којих бежи. Низом дигресија аутор утиче на читаоце.

Петровићева реченична структура је једноставна, слике надахњују, језик је разговорни. Реченица је лишена компликованијих и гломазнијих књижевних конструкција, „слободна”, са специфичним ритмом и интонацијом, одише једноставношћу и прецизношћу. Разговорни стил је у функцији непосредности, те је то још један од разлога зашто би овај путопис био занимљив ученицима и млађој публици; његова предност је у језику и стилу који је довољно приступачан ђацима. Аласово рибарење се може довести у везу са његовим стилом и разговорним језиком који је близак обичном човеку. Једноставност језика и стила подсећају на давна рибарска приговарања те се чини да је М. Петровић био упознат са стваралаштвом Петра Хекторовића и других аутора који су у таквом идиличном свету видели извор радости и надахнућа.

Након што нас је путописац заинтересовао надахнутим описима острва, непосредно се обраћа читаоцима и уводи их у свет гусара.

На страницама Петровићевог путописа срешћемо се са светом који своју изузетност види управо у томе што није изузетан, што је обичан. Путопис плени оптимизмом захваљујући једноставности и искрености. Једноставност, непосредност и интелектуалност су атрибути који карактеришу путописе Михаила Петровића. Петровић неретко коментарише, коментари успоравају или прекидају приповедање, а циљ му је да читаоце додатно подучи и прикаже оно што сматра да им је непознато. Петровић користи хипотипозу, јасно и живо описивање нечега као да је присутно и да се догађа пред нашим очима. Често прекида приповедање описима који су живи, користи приповедачки презент, те читалац има осећај да може да види описано. Неретко прави дескриптивне паузе, раван дешавања је равна нули. Таквим описима постиже ефекат реалног. Описима мотивише, распоређује и дочарава.

Петровићева путописна слика је често импресионистичка. То се најбоље уочава у описима пејзажа. Понекад Петровић одлази у лирски опис природе, иако то начелно не жели - Сутрадан изјутра, изашли смо на палубу брода, били смо обасјани скоро тропским сунцем. Ветар се био скоро потпуно стишао и повриина океана је била скоро као огледало. Тада су нам се на површини воде, пред очима указали необични призори. 
Непрегледно мноштво риба око брода чинило је да вода око њега ври... Делфини су се играли, колобатали и превртали поред самог брода (Петровић 1933: 10).

Слично овом опису, Петровић је очаран рибама, те су и ти описи лирски, обојени сентименталношћу - Кад се море утиша, ова риба излази на површину воде и задивљује својим плавим и пурпурним бојама са металним сјајем (Петровић 1933: 11). Иван Ђаја истиче да Петровић није безосећајан када говори о природи или рекама (води). Петровић прибегава објективности из бојазни да верно не изнесе истину или документарност. Плодност и разноврсност Петровићевих описа изазивају богатство доживљаја. Мноштво слика и пишчева речитост маме читаоце. Приликом описа, писац скрене у ону фину књижевност, али се убрзо врати свом енциклопедијском стилу. Врло строго се држи одређених правила при приповедању. Јасно и храбро отпочиње приповедање, прати примарну визију, али прави и приповедачке дигресије. Негује изразиту хијерархију исказа, а приповедање је логично и увек исцрпно, стално испитује узроке и последице (Павловић 1969: 320). У описима се види узбуђење које се будило у писцу у тренутку путовања, али и касније док је радио на својим рукописима. У жељи да прикаже читаоцима све оно што је до тад читао или чуо, Петровић умеће друге текстове. Подсећање на туђе мисли чини путопис убедљивијим. Писац у путопису испољава таленат, образовање, начин размишљања и властите погледе на свет.

Централна тема је гусарство, а у ширем тематском кругу су и међуљудски односи, историја, географија, економија.

Гусарство постоји одвајкада. У правом гусарству, много је витештва. Из Аласове књиге сазнајемо шта су повод, узрок и мотиви гусарења. Распрострањено је мишљење да су гусари морски разбојници, али таква идеја је сасвим погрешна, како нас учи Михаило Петровић. Право гусарство, не разбојништво, је трајало три века, ишчезло и више се није вратило. Оно је важан део светске историје, који је оставио трага у људским животима. Појаву гусарства везујемо за Шпанце и Колумбово отриће Америке 1492. године. Како су Шпанци сматрали да им по првобитном проналаску припада благо и земља коју су први открили, исто тако сматрају да им други народи то не смеју и не могу одузети, те почињу да нападају друге бродове и умањују њихово право на плен. Временом, смелост и дрскост гусара расте. Становници острва, огорчени поступцима Шпанаца претварају се у њихове заклете непријатеље и тако настају „буканири”, који ће се касније преметнути у „флибустире”. Петровић отвара путопис и према другим жанровима - описи гусарства су често и бајковити, говоре 
о једном ишчезлом и другом времену, другој историји и лепоти живота на другом крају света.

У прва два поглавља читалац се сусреће са местима на којима је путописац боравио. Петровић пажљиво бира историјске чињенице које ће истаћи, а нарочито етимолошка предања за која сматра да би била изразито интересантна читаоцима. Највећу инспирацију је проналазио у рибарству. Због тога су најлепши и најзанимљивији описи у овом делу посвећени рибарењу. Описима се писац удаљава од свог непристрасног стила и допушта машти и чаробним дескрипцијама да превладају. Без намере да покаже своју велику ерудицију, Петровић се труди да своје знање пренесе. Осетљив је на призоре у природи који су праћени фотографијама, а оне визуелно читаоцима дочаравају пејзаже разних предела.

Путопис показује Петровићеву опседнутост морем, водом, рекама. Море је велика тема, загонетка и опсесија. Лепота путовања се мери лепотом виђених вода. Лепоту мора Петровић види као природно богатство које припада свим људима, а опседнутост водама кључ је изузетних лирских пасажа.

У другом делу открива се порекло гусара, њихове биографије, детињство, одрастање, утицаји, узроци и мотиви бављења гусарењем. Описују се гусари Денкерка, Нанта, Сен Малоа, Труен, Франсоа Лемем и многи други. Петровић интерпретира њихове подвиге, умеће анегдоте, а нарочиту пажњу посвећује острву Корњача и гусарима који су се борили за превласт над њим. Тај свет, потпуно ослобођен од свих правила, функционисао је на врло аутентичан начин. Гусарске борбе заузимају важно место. Оне ће привучи ученичку пажњу - њихови детаљни прикази показују младим читаоцима храброст на делу. У тим случајевима Петровић није ни на чијој страни, он је свезнајући приповедач који верно и детаљно преноси догађаје.

Коментарима Петровић утиче на читаоце, они имају апелативну структуру - аутор тако исказује свој став кроз њих, обраћа се читаоцима. Он повезује путописни свет са светом читаочеве стварности. Коментар служи Петровићу као средство посредовања између света књижевног дела и читаоца. Коментарима писац износи идеју дела, тежњу и потребу за (ca) знањем. Својим једноставним и разумљивим језиком, писац учи (младе) читаоце заборављеним вредностима. Обраћа им се непосредно, чиме ствара чврсту везу како би могао да несметано износи своја размишљања.

Регуларно гусарство везивано је за француске гусаре, најпознатији гусари баве се морским пиратством до пред крај наполеонске епопеје. Нестанком флибусирства нестаје и регуларно гусарење, а превласт до- 
бијају морски пирати. У једном од поглавља писац приказује разлике између пирата и гусара. Капетан гусарског брода је имао званично краљево овлашћење да задржава непријатељске бродове. Регуларно гусарство је трајало од 16. до 19. века. Гусари су приказани „реалистички”, верно, нефикционално, а прича о њима је проширена и навођењем анегдота из женског пиратства.

Гусарски свет, у односу на свакодневни живот, било данас, било у прошлости, делује у знатној мери авантуристички, привлачно, занимљиво, управо зато је путопис У цзарству гусара такав. На непоновљив начин, надахнуто, верно, са анегдотама, документима и фактима Петровић говори о гусарењу.

Гусарске борбе представљају главну тему путописа. Уочљив је паралелизам између наших хајдука и гусара. Модел борбе одликује се строгим принципима, изграђеним системом борбе и ефикасним нападањем. У првом плану је херојска акција. Гусари су довитљиви и промоћурани, али и силни. Приказивање борби доводи до сажимања времена, тиме се постиже убрзање наративног тока. Борбе путопис чине динамичнијим. Ново у Петровићевом путопису јесте психолошка карактеризација јунака, потпомогнута податацима из биографије и детињства гусара. Михаило Петровић се труди да не заузима став судије - Био је толико одважан и дрзак, да је покаткад сам, или само са једним другом нападао читав одред Шпанаиа. Учинио је у више наврата невероватне морске подвиге... Моћне галије су за тили час биле плен малог чамиа (Петровић 1933: 156).

Када говори о народима, Петровић је добро упознат са карактеристикама црнаца или Европљана о којима пише. Европљани су тешко прилагодљиви, док црнцима ништа не смета. Урођеници су говорљиви, радни, доброћудни и услужни. Свест о себи и свест о другом у делу има улогу да идентификује нас и њих. Пошто је Петровић доста читао о урођеничком народу, чини се да га посматра са симпатијама и са жељом да га још боље упозна.

Хумор у путопису није нарочито изражен, међутим, није ни стран аутору. Комичне епизоде су врло ретке, примећују се када се путописац „опусти”. Комично портретисање види се приликом описа доброћудног гусара Менжуена који лепо моли за пажњу. Који још свиреп гусар моли било кога било шта? Сличну комична епизода се запажа и након капетановог остављања путника на Тенерифима - Епилог комичног излетничког путовања био је велики број тужби које су учесници уњему, чим су стигли y Енглеску, поднели властима против бродарске компаније, капетана, особља брода и против својих сапутника са којима су се на путу вређали 
и тукли. Тако се завршило организовано излетничко путовање око света... које је изазвало буру смеха у изеломе свету (Петровић 1933: 108). Са становишта ученика који се смеје учесницима и појавама описаним у путопису, хумор представља афективну реакцију на комични аспект уметничког дела и стваралачке поступке којима је тај свет остварен. Хумор Михаила Петровића се огледа и заснива на емоционалној подлози коју можемо пронаћи у саосећајности и наклоности ономе што описује. Хумор представља разумевање људске лудости или људских слабости. Петровићев (ретки) хумор разведрава, оплемењује и поучава. Намера му је да придобије читаоца за заједнички, доброћудни смех разумевања. На тај начин се читалац приближава ликовима и непосредно усваја искуство њихових поступака. Весели и ведри смех представља афективну реакцију читаоца на комичну суштину ситуације у којој су се путници нашли и изражава симпатију и разумевање за њих. Умесно подстицан разговор наставника са ученицима о томе шта их је забавило и насмејало води ка тумачењу и вредновању уметничког дела, али и критичком просуђивању проблема шта је и зашто било смешно. Употреба смешних и шаљивих елемената утиче на склоп путописа, на ауторску дистанцу и однос са читаоцима. Посредством хумора Петровић постиже одређени степен комуникативности са читаоцем. Хумористични пасажи пружају доста уметничких података о гусарима, о њиховом карактеру, о карактеру људи уопште, адекватније представљају путопис, обликују ликове и дочаравају расположење, показују интелектуалност писца, али показују и ефекат смешног који настаје укрштавањем супротних животних навика. Невелики број хумористичких одломака побуђују смех код ученика и пријатне доживљаје, па се та места извајају као занимљива, привлаче пажњу и дуже се памте.

Сазнања до којих су ученици дошли током анализе путописа, као и утиске који су били измамљени током часова наставник оставља за крај разговора. Ученици издвајају цитате или описе који су им се нарочито допали, разговарају о лепоти путовања и процењују уметност Михаила Петровића. У царству гусара ученици виде Петровића као једног ствараоца који је жудео да што више исприча, као највећег књижевника међу математичарима и највећег математичара међу књижевницима. Жанровски, ова књига је много шира од уобичајене дефиниције путописа. Након доживљајног, истраживачког читања и проблемског приступа ученици су путовање воденим путевима видели као сажимање Петровића са морима и океанима. Лепоти пејзажа и описима природе претходе дубоки доживљаји. Путописац истраживачки помно покушава да сазна што више и завири у душу сваке земље и сваког гусара. 


\section{4. Професор математике у основној школи}

Путописи Михаила Петровића Аласа, као што је већ поменуто, не спадају у сам врх тог жанра у српској књижевности, али одишу ведрином, једноставношћу и радошћу, па имају и своју немалу књижевну вредност. Суштина проучавања Петровићевог текста је савладавање књижевнотеоријског термина и доживљајно читање дела. Дело је подесно за примену у педагошкој пракси јер је пријемчив стил погодан за младе читаоце, много дигресија и коментара утичу на критичко промишљање и развијање свети код ученика. Ученик путује са путописцем који га је придобио занимљивим стилом, њему разумљивим. Често у наставној пракси ученици одбијају да читају оно што им „није јасно”, те се јавља одбојност према одређеним књижевним делима, док са Аласовим путописом то не би био случај. Стилска средства, као и синтаксичка решења, примерена су ученицима основне школе, те је то још једна од предности коју би обрада овог књижевног дела имала. Тумачење централног мотива био би изазов ученицима. Изучавање нових појмова и сазнавање о гусарству буди код ученика жељу да прошире своје знање и обликују своју критичку мисао. Укључивање различитих жанрова у путопис погодно је тле за њихово секундарно дефинисање, поткрепљено конкретним примерима. Природа буди различита осећања, описи обилују стилским фигурама које откривају емоције путописца, али исто тако буде емоције и код младих читалаца. Ђаци имају слободу да коментаришу лепоту природе, да маштају о местима и тако буде креативну страну, која се са појавом компјутерских игрица и брзих садржаја нуђених на интернету, смањује.

Креативно промишљање је основна предност путописа као жанра. Код читалаца се јавља потреба да пробуде властиту машту, да у својој души замисле места и гусарске борбе. Откривањем емоција и доживљајним читањем ученици јаче доживљавају књижевно дело. Посебно интересовање европског човека за далеке пределе постоји и данас. Чудни обичај и необичан изглед других народа побуђују жељу да се сазна више о њима. У путопису Михаила Петровића наставник проналази начин да ученицима имагинација живне. Логичност и исцрпност као карактеристике стила доводе до читаочеве посвећености. Ненагомилавање речи и равномерно приповедање су врло примамљиви ђацима. Писац на умешан и (педагошки) погодан начин гради и нијансира своје ликове и ситуације. Описи и разноврсне приче подстичу имагинацију код ученика, заокупљују њихову пажњу. Путовања мењају човека, а обрада путописа Михаила Петровића у основној школи би, ако не променила ученика, онда бар заинтересовала за будућу промену и рад на себи. 


\section{ЛИТЕРАТУРА}

Петровић 1933: М. Петровић, У изарству гусара, Београд: Српска књижевна задруга.

Анђелковић 2019: М. Анђелковић, Михаило Петровић Алас-Живот, дело, време, Београд: Српска академија наука и уметности.

Богдановић 1933: М. Богдановић, XXXV коло Српске књижевне задруге. Београд: СКГ.

Вучковић 1979: Р. Вучковић, Поетика хрватског и српског реализма. Сарајево: Светлост.

Делић 2000: Ј. Делић, Исидора Секулић у традииији српског путописа, Исидоријана, бр. 8/9.

Деретић 2013: Ј. Деретић, Историја српске књижевности. Зрењанин: Sezam book.

Живковић 1990: Д. Живковић, Теорија књижевности. Београд: Завод за уџбенике и наставна средства.

Николић 1999: М. Николић, Методика наставе српског језика и къижевности. Београд: Завод за уџбенике и наставна средства.

Павловић 2005: М. Павловић, Неке особености стила Михаила Петровића и његов значај за стилистику. Београд: Филолошки факултет.

Пековић 1998: С. Пековић, Путописи Михаила Петровића. Београд: БИГЗ.

Поповић 2007: Т. Поповић, Речник књижевних термина. Београд: Логос Арт.

Росандић 1986: D. Rosandić, Metodika književnog odgoja i obrazovanja. Zagreb: Školska knjiga.

Росић 1996: Т. Росић, Фактографија естетског у путописној прози Јована Дучића, О Јовану Дучићу: зборник радова поводом педесетогодишњице смрти, Београд.

Секулић 2005: И. Секулић, Белешка уз путопис Љубав у Тоскани, Књига о Црњанском. Београд: СКЗ.

Солар 1976: М. Солар, Теорија књижевности. Загреб: Школска књига.

Трифуновић 1969: Д. Трифуновић, Летопис живота и рада Михаила Петровића. Београд: Српска академија наука и уметности. 
Jelena G. Grebović

\author{
METHODOLOGICAL APPROACH TO THE TRAVELOGUE \\ IN THE EMPIRE OF THE PIRATE MIHAILO PETROVIĆ ALAS
}

\title{
Summary
}

The paper analyzes of the travelogue in the Empire of the Pirates by Mihailo Petrović Alas, with the basic intention to explain the specific expression and style of Mihailo Petrović. The features of Petrović's travelogue and its specificity are presented. The theoretical part is supported by adequate examples of the analysis of Petrović's work. The language is spontaneous, simple and understandable. The sentences are syntactically clear. The essence of the paper is focused on the presentation of travelogues as a suitable genre for processing in teaching practice. The text is more than a grateful support for methodical processing in primary school because it awakens the imagination of students, and that is above all a sufficient motivation for a literary work to be processed in a valid methodical way and thus awaken conscious student activity. Special value is the expansion of the focus towards the study of Serbian travel prose, which opens new spaces for future interpretations.

Keywords: travelogue, Mihailo Petrović Alas, In the Empire of Pirates, methodology, approach, Serbian literature. 